\title{
РАЗДЕЛХУІ. БИОЛОГИЯ
}

\author{
Васильева Т.Н. \\ Анализ фитоценозов овражно-балочного комплекса Центрального Оренбуржья \\ Оренбургский научный центр УрО РАН (отдел геоэкологии) \\ (Россия, Оренбург)
}

doi: $10.18411 / \mathrm{sr}-10-04-2018-58$

idsp: 000001:sr-10-04-2018-58

\section{Аннотация}

Анализ фитоценозов проводили на участке, находящемся в районе посёлка Ленина Оренбургского района Оренбургской области. В районе исследования выявлено 149 видов растений, представленных 35 семействами. Наибольшее видовое разнообразие растений имеет транссупераквальная фация - 79 видов из 24 семейств, наименьшее - 52 вида из 15 семейств северная супераквальная фация. В условиях естественного увлажнения и дренажа почв овражно-балочной системы продуктивность фитоценозов уменьшается от трансупераквальной фаций $(3,72$ т/га) к супераквальной фаций $(2,52$ т/га). Фации овражно-балочных систем отличаются большим разнообразием видового состава и продуктивностью фитоценозов. Однако присутствие признаков продолжающейся водноветровой эрозии свидетельствуют о недостаточности растительного покрова. Для придания эрозионной устойчивости необходимы дополнительные мероприятия, например агротехнические приемы: залужение, посадка вдоль границ оврага кустарников (бобовника, акации, караганы кустарниковой, и д.р.).

Ключевые слова: биопродуктивность, овражно-балочная система, ландшафтная фация, фитоценозы, эрозия.

\section{Введение}

Овражно-балочные комплексы Оренбургской области занимают 211,8 тыс. га (по данным НПП "Гипрозем"). Образование овражно-балочных систем влечет за собой вывод из оборота больших площадей пахотных земель, непригодных для сельскохозяйственного использования, что обусловливает необходимость дальнейшего исследования балочных систем с целью придания им эрозионной устойчивости и более продуктивного их использования в дальнейшем [1-3, 5, 6].

Цель - анализ фитоценозов овражно-балочного комплекса Центрального Оренбуржья.

\section{Материалы и методы}

Контрастные формы мезорельефа рассмотрены на примере овражно-балочной системы степной зоны Оренбургского района в бассейне р. Сакмара. Исследования проводились на участке, находящемся в районе посёлка Ленина. Овражно-балочную систему классифицировали по фациям согласно [4, 7]:

1. Субаквальная фация;

2. Транссупераквальная фация;

3. Группа супераквальных фаций на южном склоне;

4. Группа супераквальных фаций на северном склоне.

В исследованиях были применены общепринятые методики [8].

\section{Результаты и обсуждение}

По мере удаления от речных долин встречаются контрастные формы мезорельефа. Овражно-балочные системы формируются на возвышенных хорошо дренируемых местах. 
Такая система не только прирастает за счет эрозии, но и заполняется отложениями. Динамика эрозионно-аккумулятивного процесса проявляется, в том числе, в изменении склонов внутри оврага.

Почвенный покров исследуемого района представлен черноземами обыкновенными, в разной степени смытыми на склонах. Гранулометрический сосав в основном глинистый и тяжелосуглинистый. Овражно-балочная система образована в результате водной эрозии, а именно из-за размыва почвенно-грунтовой толщи стекающими со склонов дождевыми и талыми водами.

Исследование овражно-балочной системы показало, что ее склоны представлены вертикальными, крутыми, и в некоторых местах ступенчатыми со следами смещения, то есть видны оползневые подвижки. Глубина овражно-балочной системы колеблется в пределах 3-3,5 метров, длина составляет 800 метров. Нижняя часть склонов иногда покрыта осыпями, отдельные участки оврага имеют вид небольших ущелий. Склоны можно разделить на две части: верхнюю - слабо увлажненную из-за стока воды и обедненную из-за смыва почв и нижнюю - более увлажненную и обогащенную намытыми плодородными горизонтами почв. B основном днище широкое, сформированное наносами, хорошо развита травянистая растительность. Склоны овражно-балочной системы задернованы местами до 80-90\% (правда, не известно, при каких условиях это достигается, ведь имеются и не задернованные склоны). В овражнобалочных системах сохраняется естественная растительность.

Общее количество видов, выявленных в районе исследования, исчисляется 149 из 35 семейств, из них насчитывается ксерофитов - 13, ксеро-мезофитов - 18, мезофитов 107 , мезогигрофитов -8 , гигрофитов -2 , гидрофит -1 .

Субаквальная фация, периодически затопляемая и расположенная в пониженных элементах рельефа, характеризуется камышово-разнотравной формацией. При подсчете процентного соотношения от общего числа видов данного участка отмечали гидрофитов $1 \%$, гигрофиты - 3\%, мезогигрофиты - $12 \%$, мезофиты - 65\%, ксеро-мезофиты - $19 \%$. Вегетация части растений проходит под водой, что существенно влияет на продуктивность фитоценозов субаквальных фаций. Поэтому воздушно-сухая масса растений достигает 3,91 т/га, а высота 150-160 см.

Транссупеаквальная фация, расположенная в пониженных элементах рельефа над руслом оврага, характеризуется разнотравно-злаковой формацией растений и имеет наибольшее видовое разнообразие растений 79 видов из 24 семейств. Здесь на долю ксеро-мезофитов приходиться 16\%, мезо-гигрофитов - $11 \%$, мезофитов - 73 \%. Высота травостоя достигает 60-90 см, что почти в два раза ниже растений в субаквальной фации. При этом фитомасса в воздушно-сухом состоянии не значительно меньше, и составляет 3,72 т/га. Это объясняется видовым составом растений.

В супеаквальной фации в отличие от субаквальной и трансупераквальной фации из экологического ряда исчезают гигрофиты и гидрофиты, превалируют травянистые формы ксерофитного экологического ряда. Общее количество видов, произрастающих на южном склоне в супераквальных фациях достигает около 69, относящихся к 20 семействам, причем на долю ксерофитов приходится - 9\%, ксеро-мезофитов - $26 \%$, мезофитов $-57 \%$, мезо-гигрофитов - 8\%. Высота травостоя достигала до 90 см, фитомасса в воздушносухом состоянии была 2,52 т/га.

Биоразнообразие растительности и продуктивность фитомассы зависит от экспозиции склона. Южный склон лучше задернован и освящен, чем северный. Поэтому относительная площадь проекции фитоценозов на поверхности почвы южного склона достигала в среднем $60 \%$, а северного склона - 50\%. Количество видов, произрастающих 
на южном склоне значительно больше, чем на северном. Общее количество видов, произрастающих на исследуемых участках супераквальных фаций северного склона достигала 52, относящихся к 15 семействам, при этом на долю ксерофитов приходится $2 \%$, ксеро-мезофитов - $21 \%$, мезо-ксерофитов - $2 \%$, мезофитов $-64 \%$, мезо-гигрофитов $11 \%$. Высота травостоя супераквальных фаций северного склона достигала до 80 см, фитомасса в воздушно-сухом состоянии была 2,33 т/га.

От степени увлажнения почв зависит видовое разнообразие растений.

В овражно-балочной системе района исследования наблюдаются признаки эрозии: разрушение почвенных горизонтов с выходом горных пород, нарушение дернового слоя, различимы обнаженные корни растений. Видны проплешины, когда общее проекционное покрытие местами достигает от 0 до $20 \%$.

Следовательно, биоразнообразие, продуктивность и высота растений фитоценозов исследуемых участков зависит от ландшафтного расположения, содержания влаги в почвах.

Фации овражно-балочных систем отличаются большим разнообразием видового состава и продуктивностью фитоценозов. Однако присутствие признаков продолжающейся водной эрозии свидетельствуют о недостаточности растительного покрова. Для придания эрозионной устойчивости необходимы дополнительные мероприятия, например, залужение, посадка вдоль границ оврага кустарников (бобовника, белой акации и др.).

\section{Заключение}

Фации овражно-балочных систем отличаются большим разнообразием видового состава и продуктивностью фитоценозов, зависят от ландшафтного расположения, содержания влаги в почвах. Наибольшее видовое разнообразие растений имеет транссупераквальная фация - 79 видов из 24 семейств, наименьшее - 52 вида из 15 семейств северная супераквальная фация. В условиях естественного увлажнения и дренажа почв овражно-балочной системы продуктивность фитоценозов уменьшается от трансупераквальной фаций (3,72 т/га) к супераквальной фаций $(2,52$ т/га).

Присутствие признаков продолжающейся водной эрозии свидетельствуют о недостаточности растительного покрова. Для придания эрозионной устойчивости необходимы дополнительные мероприятия, такие как залужение и посадка вдоль границ оврага кустарников (бобовника, белой акации и др.).

$$
* * *
$$

1. Андреев Н.Г. Луговедение. М.: Агропромиздат, 1985. 255 с.

2. Бондарев В.П., Зорина Е.Ф., Ковалев С.Н. Гидролого-морфометрические характеристики овражнобалочных систем центра Русской равнины. Геоморфология. 2000. 2: 52-58.

3. Васильева Т.Н. и др. Оценка биоресурсов и продуктивности фитоценозов Центрального Оренбуржья. Вестник ОГУ. 2015. 10: 208-211.

4. Глазовская М.А. Геохимические основы типологии и методики исследований природных ландшафтов. М.: Московский университет, 1964. 229 с.

5. Ларин И.В. Луговодство и пастбищное хозяйство. Л.: Агропромиздат, 1990. 551 с.

6. Николаева Н.Е. Овражно-балочные земли северной лесостепи и их рациональное использование. Автореф. дисс. ...к. с-х. н. Курск, 1998. 21 с.

7. Полынов Б.Б. Избранные труды / Под ред. И.В. Тюрина, А.А. Саукова. М.: Изд-во АН СССР, 1956. 751 с.

8. Рябинина 3.Н., Князев М.С. Определитель сосудистых растений Оренбургской области. М.: Тов. науч. изд. КМК, $2009.758 \mathrm{c}$. 